\title{
Democratic Education for Hope: Contesting the Neoliberal Common Sense
}

\author{
Katariina Tiainen $^{1}$ (D) Anniina Leiviskä ${ }^{1}$ (D) $\cdot$ Kristiina Brunila $^{2}$ (D) \\ Published online: 9 February 2019 \\ (c) The Author(s) 2019
}

\begin{abstract}
This paper provides a reinterpretation of Paulo Freire's philosophy of hope and suggests that this interpretation may function as a fruitful ground for democratic education that aims to contest the prevailing neoliberal 'common sense'. The paper defines hope as a democratic virtue required for resisting the discursive practises and affective mechanisms associated with the contemporary neoliberal ethos-those, which Carlos Alberto Torres characterizes as the "neoliberal common sense" and Lauren Berlant as "cruel optimism". Conclusively, the paper constructs three principles for democratic education - history as possibility', 'the ethics of intervention', and 'democratization'-which are intended to function as a foundation for democratic education through which the virtue of hope can be fostered. These principles are argued to form a basis for reviving the political dimensions of education and thus allowing collective transformative action.
\end{abstract}

Keywords Paulo Freire $\cdot$ Hope $\cdot$ Democratic education $\cdot$ Cruel optimism $\cdot$ Neoliberal common sense

\section{Introduction}

We are living in societies characterized by structural injustices, which are tied to the functioning of market economy and neoliberal rationality in many ways. However, the particular feature of contemporary late-capitalist societies is that these injustices manifest themselves in ways that are increasingly hard to recognize and intervene in. Paulo Freire formulated his philosophy of hope as a response to the ideological operations of capitalist societies, which he recognized as causing political inaction and impeding collective endeavours of transformative political struggle for democratization. Freire saw this "democratic inexperience" characteristic to capitalism as major impediment to hope (Freire 1997, pp. 88, 91; Freire 1998c, pp. 29-30).

Katariina Tiainen

katariina.tiainen@helsinki.fi

1 Department of Education, Faculty of Educational Sciences, University of Helsinki, Siltavuorenpenger 3 (Room 152), P.O. Box 9, 00014 Helsinki, Finland

2 Department of Education, Faculty of Educational Sciences, University of Helsinki, Siltavuorenpenger 5A, P.O. Box 9, 00014 Helsinki, Finland 
More recently, through her notion of "cruel optimism", Lauren Berlant (2011) has characterized the way the neoliberal culture directs individual hopes and dreams towards goals that serve neoliberal economy rather than collective political transformation. Berlant's notion of "cruel optimism", which refers to the affective mechanisms of the neoliberal rationality or "common sense", was born out of the observation that people continue to construct their lives and identities around the pursuit of such desirable and socially esteemed objects as upward social mobility, job security, equality and economic wellbeing, although these objects have become increasingly difficult to redeem under today's neoliberal restructuring. According to Berlant (2011), the pursuit of these objects gives the individual a sense of purpose and meaning in life, but the downside is that because these objects remain unattainable to most, their pursuit merely engages the individual in a constant struggle of self-management and self-improvement that ultimately keeps her from engaging in collective political action.

Although written in a different time and for a different kind of society, the central message of Freire's philosophy of hope is anything but outdated, as he saw the functioning of neoliberalism as destructive for collective human hope and solidarity. For Freire, hope is an essential human quality that enables resisting the "culture of silence" and cynical discourses that the neoliberal ideology entails. However, from a Berlantian perspective, even more than the hopelessness and despair that Freire witnessed among underprivileged citizens in the society of his time, the antithesis of hope in late-capitalist societies is the false form of hope associated with unattainable objects to which people become affectively attached, but which are not realistically within their reach. Nevertheless, as the capitalist system only provides objectives that serve its own reproduction, for the individual it is more meaningful to pursue them than have no goals or purpose at all. The cruelness thus rests on the fact that the individual is affectively attached to pursuing these unattainable and empty objects and holds on to the illusion of their necessity, although these goals are ultimately harmful to the individual's well-being.

This present neoliberal restructuring, described by Berlant by the notion of "cruel optimism", is particularly interesting from the perspective of education. Namely, Western democratic societies have typically been characterized by meritocratic thinking and especially the idea that the type of education one receives is intimately associated with the possibility to attain certain economic and social goods. However, in contemporary late-capitalist societies, these goods are increasingly difficult to cash in: education no longer guarantees economic or job security or an esteemed position in society. At the same time, the responsibility for attaining these desired objects - as well as the failure to attain them-is placed on the individual (Paolantonio 2016; Brunila and Siivonen 2016). As the focus and responsibility is placed on the individual, attention is drawn away from structural injustices. Accordingly, these tendencies are tied to the fundamental depolitization of education and thus to the diminishing of the opportunities to influence democratization of society by educational means.

In this article, our aim is to respond to the issues highlighted by Berlant by using Freire's philosophy of hope and his idea of democratic education as our starting point. More specifically, our aim is to outline central principles of democratic education, the purpose of which is to disclose and replace the individualizing educational discourses and policies with educational practices that centre on the idea of democratization as a form of collective hoping. In the following parts of the paper, we first characterize the Freirean ontology of hope on which democratic education is built and, secondly, we define hope as a democratic virtue. Next, we describe in more detail the false and optimistic hopes engendered by neoliberal common sense-hopes, which we suggest should be exposed and resisted by means of democratic education. Finally, we outline the core commitments of democratic 
education for hope by building on our reinterpretation of three Freirean notions: (1) history as possibility, (2) ethics of intervention, and (3) democratization. We suggest that committing to these principles can create conditions for an educational practice in which individualized struggles for continuous self-management and improvement can be transformed into political and collective struggles for a more just social order.

\section{Democratic Virtue of Hope}

"Ontological need", "ontological vocation", "essential component", "critical acceptance of incompleteness" and "untested feasibility" are some of the expressions used by Freire to describe hope (Freire 1997, p. 44, pp. 53-55, 1998b, p. 69, 1998c, pp. 8-9, 98-99). Freire never developed the concept of hope systematically nor did he provide a straightforward definition of it. Instead, Freire, and the tradition of critical pedagogy after him, have used the concept of hope to refer quite loosely to a variety of ideas concerning democracy, citizenship and critical engagement in utopian struggles towards social transformation. This ambiguity is one of the reasons Freire's critical pedagogy has faced much criticism over the years: it has been blamed for dreamlike utopianism, lack of tangibility, and inner contradictions that have made it difficult to put to use in educational practice (Cho 2010; Glass 2001; Ellsworth 1989; Jackson 2007; Lather 1998; Weiler 1996, 2001).

Our aim is to define the meaning of the concept hope as it is utilized in the framework of this article, emphasizing particularly those features that are fruitful from the perspective of democratic education today. We begin our definition by describing its relation to the Freirean notion of humanization, which is the ontological foundation of Freire's political pedagogy and his philosophy of hope. For Freire, humanization is the ontological vocation of human beings as being aware of their fundamental incompleteness. Humanization thus refers to the constant struggle for transformation of both social structures and subjective consciousness following from humans' recognition of being incomplete and having to decide their own history (Freire 1970a, b, 1997, 1998c, Freire 2014). Human beings are in a constant state of "becoming more fully human" (Freire 2003, pp. 144-145) and having to define and 'make' themselves in history and in relation to an ever-changing world. The central feature of humanization is it having no predetermined end or telos; it is an openended process that can and must be defined only in relation to its opposite, dehumanization (Torres and Morrow 2002). To put it in more practical terms: humanization is a process of self-definition and self-realization that takes place in a dialogical relation with others and in regard to those tangible social conditions of injustice and non-freedom prevailing at a given historical moment. For Freire (e.g. Freire 1970a, b, 1993b), humanization is thus a process that can only be pursued collectively, together with others, and it manifests itself in collective endeavours to create and recreate the social world.

Torres and Morrow (2002) suggest that there is an internal link between the ontological vocation of humanization and democratization in Freire's philosophy. Freire (1996, p. 146) himself also explicitly draws this connection between humanization and democratization by indicating that there is "... an ontological and historical foundation for the political struggle around democracy and its permanent improvement". In another context, Freire (1997, p. 107) also states that the value of hope-that is, what makes it worthwhile to put our hopes "into the fight"-appears only in improvement of democracy and overcoming of social injustice. In these contexts, Freire thus uses humanization and democratization as parallel concepts. Democratization-vocation to transform social structures and institutions toward more dialogical, equal and just forms in the light of the society's prevailing 
injustices - can thus be viewed as the way Freire saw the ontological vocation of humanization being materialized in actual historical and social circumstances.

Hope is a necessary condition for this permanent struggle for transformation that characterizes the process of humanization and thus also democratization; it is an ontological need that motivates and orients this struggle. However, as Torres and Morrow (2002) and Webb (2010) indicate, characterizing hope as an ontological need does not mean that it is always or automatically available. Rather, hope can easily be fixated on some distorted or ideologically manipulated objective. Accordingly, educational practices need to elicit hope by anchoring it to objectives worth pursuing. Although Freire himself does not define hope as a civic virtue, the way he utilizes the notion of hope is parallel with theories of citizenship education where hope is viewed as a disposition of democratic citizens; that is, a virtuous inclination to act in ways that benefit citizens' collective existence (e.g. Callan 1997; Gutmann 1987; White 1996). In our definition of democratic virtue, we lean particularly on Patricia White (1996), since she draws a connection between hope and democratic virtue in a way that is particularly fruitful to our discussion.

Following White (1996, p. 2), democratic virtues can be defined as positive dispositions “...that citizens require if democratic institutions are to flourish". White (1996) highlights hope as one of the central democratic virtues and further emphasizes that democracy does not only consist of procedures of deliberation but for democracy to flourish, the values underlying these procedures as well as citizens' sentiments and dispositions to live by them are equally important. White distinguishes "social hopes" (p. 8) from private forms of hoping, using the first to refer to hopes that relate to the whole community and play a central role in the formation of citizens' experiences. White further distinguishes democratic hopes from hopes associated with forms of social hoping in which the telos or the desired end state of society is predetermined (as in classical Marxism or Christianity). She stresses that democratic hopes are characterized by their association with value pluralism and thus embody a view of an open future. Democratic hope thus means giving up the idea that the object of hope is unitary, and its realization is inevitable.

White's definition is largely compatible with Freire's own understanding of hope: both emphasize the open-ended nature of hope, and the connections between hoping, democracy and democratization. Through White's definition, hope also becomes more tangible from an educational viewpoint, as it can be seen as a disposition or a quality to be cultivated through education. Moreover, viewing hope as a democratic virtue brings about consistency to the somewhat ambiguous conceptualization of hope that is characteristic of the tradition of critical pedagogy. This point of departure also turns the focus on the subjectivities construed through education and away from teacher-intellectuals, this focus being one of the criticized features of Freire's pedagogy (e.g. Ellsworth 1989; Fischman and Haas 2009).

However, departing from White's liberal democratic framework, for Freire, hope is not a disposition with a solely positive content: namely, Freirean hope is always as much about "denouncing" the present injustices and resisting them as it is about "announcing" the desired, more human world (Freire 2004, p. 105). Accordingly, as a merger of Freire's original understanding of hope and White's definition of hope as a virtue, we define hope as a democratic virtue or disposition of citizens that enables, first, collectively intervening in present injustices and resisting adaptation to the unjust conditions of society and, second, engaging in collective endeavours to define a utopic vision of a better society.

As a virtue of a democratic citizen, hope can be seen as involving several dimensions and presuppositions. Perhaps the most essential part of the virtue of hope is its transformative-practical element: hope never consists of mere wishing or passively waiting for a 
desired affair to occur but is always associated with agency and transformative political action driven by an objective considered as worth pursuing (Bovens 1999; Crapanzano 2003; Meyer 2010; Moellendorf 2006; Smith 2010). Hope is thus deeply intertwined with a continuous desire and vocation to transform society, its institutions and structures toward more just forms in the light of society's prevailing injustices. In Freirean terms, to foster hope as a democratic virtue thus presupposes obtaining a critical distance to tangible present conditions for closer understanding of the injustices and operations of power within this present. Moreover, it entails imagination and a vision of a possible future world that is more human and just than the present one (see also Halpin 2003). Furthermore, the concept of hope significantly differs from mere emotion or feelings such as passion, desire, wishing, and optimistic thinking in that its affective dimensions cannot be distinguished from the knowledge of society or the willingness and possibility to act (Day 1991; Van Hooft 2011; Mittleman 2009). Hope as a virtue should thus be understood as a whole, combining cognitive-affective and transformative-practical elements (Bovens 1999; Smith 2010; Webb 2013, 2010) all of which should also be taken into account and incorporated in practices of democratic education. ${ }^{1}$

We thus suggest that, especially complemented with the idea of virtuous democratic citizenship (e.g. White 1996), Freire's philosophy of hope can be seen as providing a productive starting point for determining the aims and outlining the practices of democratic education for contemporary democratic societies. We particularly side with Torres (1998, 2014) who has argued that hope as a virtue of citizens is urgently needed for resisting the prevailing neoliberal ideology. As both Freire and Torres $(1998,2014)$ have suggested, as an aim of democratic education, hope can be seen as an antidote to the politically immobilizing cynicism and nihilism of late capitalist societies and, as we will argue in the following section, today it is especially crucial for resisting the cruelly optimistic forms of hoping that have become a new imperative within neoliberal educational discourses.

\section{Neoliberal Common Sense and the Depolitization of Education}

Carlos Torres, scholar in the Freirean tradition of critical pedagogy, among many other scholars, has written about neoliberalism and characterized the prevailing ethos of contemporary capitalist democracies as "neoliberal common sense", which functions as a new paradigm for rational thought (Torres 2009a, 2011, 2013a, b). Torres (2011, 2013a) defines the notion of "common sense" (2011, p. 181, 2013a, p. 81) as a generalized truth about something that is based on a culturally shared understanding of values. It is a discursive set of standards or an unchallenged set of principles being incorporated into language, affecting people's sense of identity and perceptions, and constituting courses of action. Accordingly, it is particularly characteristic of such common sense that it comes to be seen as the normal way of doing things.

Moreover, neoliberal common sense makes the prevalent social practices and conditions appear as being inevitable and without "viable alternatives" (Torres and Heertum 2011, p. 6). It therefore produces deep cynicism and nihilism and gives rise to drastic feelings of giving up on the possibility of change (Torres 1998, 2009a). Ultimately, it leads to the acceptance that there is no hope and thus no need to intervene with prevailing inequalities

\footnotetext{
1 Similar associations between hope, democracy and virtuous citizenship have also been drawn by Kadlac (2014), Meyer (2010), Mittleman (2009), Moellendorf (2006) and Van Hooft (2011).
} 
or injustices (Torres 1998, 2014). Hence, the most alarming consequence of the neoliberal common sense is that it leads to political disengagement and renunciation of interventionist struggle altogether. In education, the specific features that Torres associates with neoliberal common sense include the increase of competitiveness, a strong emphasis on testing, accountability, efficiency, managerialism and mercantilism, and a drive towards standardization, privatization and decentralization of public forms of education (Torres 2009a, 2011, 2013a; Torres and Heertum 2011).

These destructive tendencies of the neoliberal common sense were already present in the societies of Freire's time and thus were a crucial motivator for Freire to develop his philosophy of hope. Like Torres, Freire also associated the loss of hope with a culture of cynicism and immersion of citizens in the unjust or inhumane present in a way that leads them to adopt a deterministic, predefined view of history. However, Freire also recognized that neoliberalism gives rise not only to cynicism and nihilism but also to "false" or individualized forms of hope which instead of being focused on the pursuit of a better future through collective political effort, are directed towards continuous self-improvement and associated with "private notions of getting ahead" (Freire 1978, p. 60; Freire and Shor 1987, p. 110).

We suggest that this Freirean notion of false hope bears some similarity to, and can be further elaborated by, a more recent concept of "cruel optimism" by Lauren Berlant (2011). ${ }^{2}$ Although Freire's notion of false hope and Berlant's cruel optimism have their roots in different theoretical traditions, in our view, both notions illuminate the mechanisms through which neoliberal common sense harnesses subjectivities in the reproduction of the present and thereby gives rise to increasing political passivity and disengagement. For Berlant (2011), cruel optimism refers to the affective way people adapt to the prevailing neoliberal ethos and the fantasies of the good life it involves, even though these fantasies remain profoundly unattainable and the promises they entail are never realized. Cruel optimism thus points to a relational dynamic in which individuals remain attached to "compromised conditions of possibility" or "clusters of promises" embedded in desired object-ideas. (Berlant 2011, pp. 23-24). The significance of these object-ideas to the individual is that they make one's life bearable by providing it with a purpose and a sense of meaning, thus the individual becomes affectively attached to pursuing them. However, as these objects remain beyond one's reach, their continuous pursuit begins to threaten the well-being of the person pursuing them. The individual becomes engaged to these highly esteemed, but empty objects and becomes occupied with cruel aspiration of these individual-oriented aims and goals, and at the same time becomes detached from critical and collective endeavours. Berlant and Freire thus both view the neoliberal common sense as redirecting the individual's activity to the maintenance of the status quo in a way that prevents the individual from pursuing alternative goals and ends. A particularly destructive consequence of false hope or cruel optimism is thus that it encourages adaptation to the present conditions rather than intervening in them. Moreover, another detrimental feature of such hope or optimism is that it makes individuals appear to be responsible for their own success or failure in life whilst hiding the underlying structures of power that largely condition the opportunities an individual has.

\footnotetext{
${ }^{2}$ We acknowledge that these notions originate from different theoretical traditions and thus cannot be treated as synonymous. Our view is rather that through Berlant's notion, Freire's idea of false hope can be connected to the more recent discussions in contemporary critical and feminist philosophies, which particularly focus on the way certain structures and relations of power operate through affects and thus engage subjectivities in the reproduction of these structures.
} 
In contemporary educational systems, these mechanisms manifest themselves, among other things, in the form of "learnification" of education, referring to the reduction of education to the construction of flexible and self-responsible subjectivities with specific predetermined skills and competencies (Biesta 2014; Paolantonio 2016; Brunila and Siivonen 2016). Differently put, people enter and undertake an education with the hope of managing and sustaining their precarious occupation in an ever-unpredictable market society (e.g. Paolantonio 2016). Consequently, education is reduced to technical training or skill-related learning that merely guides individuals towards constant attempts of selfimprovement, self-productivity, and self-representation, and thus fails to contribute to the development of political agency. This renders individuals passive in public, political, and democratic terms. This is what Freire (1997) refers to as "depolitization of education" (p. 43), which for him ultimately meant that education had failed its ethical responsibility and commitment to collective political action for social transformation.

The most far-reaching consequence of the neoliberal common sense thus seems to be that it has largely replaced collective, democratic and political forms of hoping with individualized and often unattainable hopes and imperatives that ultimately tie individuals to a continuous struggle for self-management and self-improvement. Consequently, education has gradually lost its politically transformative and utopian dimensions and become overridden by individualism and presentism. We thus suggest that under the conditions of neoliberal common sense, the primary task of democratic education is to transform the aforementioned, "cruelly optimistic" hopes and imperatives into transformative, political and collective forms of hoping that may enable what Freire (1993b, 1996, 1998b, c, pp. 98-99) refers to as democratization.

\section{Democratic Education for Hope}

In Freire's philosophy, democratic education is a form of educational praxis that strives to expose present societal injustices and demystify ideological operations of structural power in a way that may enable acting against them, and hence contribute to a radical transformation of society toward a more just, democratic and humane form. For Freire, hope lies in the possibility of critical consciousness that is oriented to the process of transformation of the unjust present reality. Thus, the democratic virtue of hope is intertwined with this idea of critical consciousness. The concept of critical consciousness refers to a transformative process of conscientization. ${ }^{3}$ Moreover, Freire's philosophy is based on the ontology of praxis and the notion of dialogue which, for him, establish the ontological and epistemological foundation for all human learning, meaning-making, and consciousness. ${ }^{4}$

\footnotetext{
${ }^{3}$ Freire's theory of consciousness has encountered much critique over the years: In the early production Freire (see, for example, Freire 1970a, b) describes the conscientization as three-level process which includes different modes of consciousness: In-transitive or naïve consciousness, semi-(in) transitive or dependent consciousness, and transitive-critical or transformative consciousness. (see. also Torres 1994, 2014) This level model is easily exposed to accusations of developmental and evolutionary movement towards a more sophisticated, upward level. Thus, it is crucial to note that Freire didn't mean that the subject would achieve some level of critical consciousness. The concept of conscientization is based on praxis and thus rather refers to process of transformative action and critical reflection.

${ }^{4}$ For Freire the subject is dialogical and communicative which means that the subject is relational being. The subject is always "in relations with" others and with the world. Freire (for example 1993b) points to Martin Buber's (2004, original 1923) notion of I-Thou and I-It, to point out that people are relational beings. The dialogical relationship is never subject-object ("I-It") relation, but always subject-subject ("IThou") relation, where the subject becomes aware of that its existence is dependent on another. As one
} 
While an extensive explication of these central elements of Freire's philosophical project falls beyond the purview of this paper, they function as a starting point for our attempt to outline educational principles for fostering hope as a democratic virtue that is required for intervening in the prevailing neoliberal common sense. The following principles-history as possibility, ethics of intervention, and democratization-bring the political dimensions of education into focus and are thus particularly aimed at resisting the all-immersive presentism and individualism-responsibilitising of the individual actor in particularthat neoliberal common sense gives rise to in contemporary educational institutions and practices.

\section{History as Possibility}

As we argued above, today's educational systems and institutions sustain and reinforce the prevailing neoliberal common sense which prevents individuals from perceiving history as a horizon of possibilities. This horizon disappears from one's sight and becomes occupied with self-centred aspirations in a way that prevents picturing alternative organizations of society. Similarly, Freire saw that the neoliberal tendencies of capitalist societies would lead to a situation in which subjects become immersed in the present thus making it difficult to see alternatives to the contemporary organization of society. Accordingly, Freire argues that the operation of neoliberalism makes the future appear unproblematic and "inexorable" (Freire 1996, pp. 188-189) and has resulted in the continuous "repetition of the present" (Freire 1998a, p. 37). He also saw education as being stripped of ethics and politics and being increasingly reduced to neutral "techniques" and "training" (2004 p. 102, 2014, p. 25).

To counteract these tendencies that hold the present as the only option and as being without alternatives, Freire poses the notion of "history as possibility" (Freire 1993a, p. 84, 1997, 53-55; 1998a, pp. 37-38; 1998c, 91, 2004, pp. 100-102). This notion challenges the mechanistic and deterministic understanding of history that renders imagining, making judgments, and choosing impossible. Seeing history as a possibility means that there is always an option to see, feel, think, and act differently, even in circumstances that present themselves as unchangeable. History as possibility is thus tied with recognition of the possibility of alternatives - that is, the idea that a radically different organization of the society is possible.

We argue that the notion of history as possibility is particularly important for cultivating the virtue of hope, as it has to do with the recognition of the limits of the present historical situation and the injustices and restrictions that this situation involves. As Torres (2009b) indicates along the lines of Freire, the ultimate responsibility of the human subject-and of democratic education - is to build consciousness of the historically and culturally formed reality, its determinations and its potentialities. Cultivating hope requires understanding a historical situation as a systematic set of constraints that it is necessary to begin to see and move against (De Lissovoy 2007, p. 443).

Footnote 4 (continued)

begins to establish awareness of these relations is where conscientization occurs. (Freire 1995, pp. 177178). Freire's philosophy represents a move towards an intersubjective or interactive interpretation of subjectivity or a view of a "dialogical subject" (Morrow and Torres 2002). As Roberts (2000 p. 151; see also Roberts 2008) also points out, Freire explicitly rejects the Cartesian "I"- the pure, atomistic ideal of individual and rational self-and replaces it with a discursively constituted and socially, culturally and politically situated "we". 
Freire illuminates this mutual interdependence of hope and the social conditions that delimit it through the concept of "limit-situation" (1998c, p. 30, 205; 2004, p. 10; Freire and Shor 1987, p. 153). Freire (1993b) argues that when the subject recognizes one's separateness from the conditioning structures, it becomes possible to see these structures as obstacles to humanization and thus as transformable. Hence, it is not the limit-situations themselves which create a climate of hopelessness, but rather how they are perceived at a given historical moment: whether they appear as insurmountable obstacles or as limitations to be overcome (Torres and Morrow 2002, p. 161). As indicated above, the prevailing neoliberal common sense, and especially its contemporary "cruelly optimistic" form, typically prevents individuals from recognizing these limit-situations. Namely, it disguises structural injustices through affective mechanisms in a way that prevents seeing these injustices as obstacles. The objects of desire that provide a sense of meaning and purpose for an individual are deeply intertwined with the structures and relations that give rise to inequality and injustice and, therefore, by pursuing these meaningful objects the individual herself takes part in sustaining and reproducing them. Hence, the way the neoliberal common sense operates significantly diminishes the opportunities to transform unjust structures.

On a practical level, democratic education can commit to the notion of history as possibility in various ways. For instance, encouraging students to discuss past political struggles and scrutinizing inequalities related to gender, ethnicity/race, disability, health, sexuality, and social class may increase students' trust in the opportunities to transform the prevailing power structures of the society through political action. Perceiving history as possibility requires recognizing that unequal and exploitative relations are established by human beings and thus can also be changed by human beings (Freire 2014; Torres 1999, 2009b). In the case of the neoliberal common sense, it is particularly important to pay attention to the past political decisions and historical developments, which have gradually transformed the global market economy toward its current form. Democratic education can emphasize humans' presence in the world as "conditioned beings" (Freire 1997, p. 37) and "beings of decision" (Freire 2003, pp. 146-147) by pointing out how the present organisation of societies is a result of concrete processes of human decision-making rather than autonomous, law-like processes. It is particularly crucial to pay attention to how different policies are legitimated by asking, for instance, who benefits from them, what reasons are given to them, and whose voices are being silenced.

\section{The ethics of Intervention}

The notion of history as possibility is inseparably associated with "the question of responsibility" and the idea of human existence as essentially ethical (Freire 2004, p. 93, 2014, p. 51). Accordingly, from the fact that human beings are not predetermined by historical and cultural structures, it follows that they must take ethical responsibility for their actions, obtain an active presence in creating and re-creating the present historical moment, and thus to "intervene with the world" (Freire 1997, p. 42; 2004, p. 101). For Freire, non-interference, ignorance and neutrality are fundamentally unethical positions as they mean refusing one's ethical responsibility, settling with the reality as it is given, or "purely adapting" to it without questioning (Freire 2004, p. 34). Accordingly, Freire's ethical position can be described as an "ethics of intervention" (see. Roberts 2000, p. 49; Torres and Morrow 2002, p. 104). For us, Freirean ethics of intervention represents the opposite of being fully immersed in presentism and thus points to tangible every-day resistance that strives to interrupt the adaptation to present conditions. 
Ethical responsibility is inseparably tied to the collective right and duty to intervene (Freire 1993b, 1997, 2004). However, we want to point out that it is important to acknowledge that neoliberal common sense has a strong tendency to transform ethical responsibility into personal guilt and self-blame concerning the situation in which one finds oneself, and especially the obstacles and misfortunes one faces. As Freire (2004) points out, such guilt is yet another way domination and governance operate: it makes the oppressed responsible for their own circumstances and thus transforms them into agents supporting the system by which they are governed. As we demonstrated above, this is exactly how cruel optimism operates - it renders the subjects responsible for their own success or failure in life and thus engages them in constant and hopeless efforts of self-centred improvement, which only reinforces present conditions and reproduces the underlying structures. Hence, we argue that democratic education based on the ethics of intervention should aim to abolish such guilt by demonstrating how 'guilty' and 'responsibilized' subjectivities are constructed through discursive practices and, ultimately, it should enable individuals to intervene with these processes of construction.

In addition to distancing oneself from the ongoing reproduction of present conditions, ethics of intervention is also about taking a clear position: as Freire (1998a) points out, education can never be politically neutral and thus it is necessary to establish "in favour of what and whom, and against what and whom" education is practiced, and "on whose behalf" (Freire 1998a, p. 46 also 1993b, 2004). An interventionist ethics thus reminds us about the importance of being awake regarding on whose side one positions oneself. Democratic education should particularly disrupt such discursive practices that operate affectively by producing restlessness, anxiety, and pervasive experiences of insufficiency in individuals. It can inspire interventionist resistance against these discourses that are violent for the individual selves by asking who benefits for me being constantly occupied with myself.

As we have indicated, in contemporary educational systems, the neoliberal common sense presents subjectivities as incompetent, as not having the latest credentials or technological skills, and as needing continuous self-enhancement. Hence, this common sense obliges the subject to take part in continuous competition between individuals over credentials, rewards and other achievements that can only be pursued individually and in a competitive setting. Democratic education must make explicit the practices and mechanisms through which subjects engage in these processes that sustain, reproduce and legitimise their own unequal positions an unjust treatment. Moreover, it should inspire engagement in everyday interventionist resistance against these discourses by encouraging individuals to move beyond self-preoccupation and to orient themselves towards shared endeavours of transformative ethical-political struggle.

Freire's ethical position emphasizes ethical and political responsibility before the world and especially for other people. "I cannot be if others are not", as Freire (Freire 1997, p. 59) points out. Therefore, democratic education for hope needs to teach students better ways to relate and be with others by revealing how discursive mechanisms operate through masking structural problems as individual and personal deficits, and thus easily end up blaming 'the other'. By inducing competitiveness among individuals, these mechanisms reduce solidarity among people and thus prevent them from forming collective goals to be pursued together. Accordingly, these mechanisms also reduce individuals' ability to emphatically relate to the positions of the marginalized and excluded. By providing historical and structural perspectives, democratic education can allow critical engagement with present and past experiences of domination, exclusion and marginalization, and to reject adaption to the discourses based on taken-for-granted assumptions concerning the marginalized others. 


\section{Democratization}

As we noted above, for Freire, the utopic vision underlying education is associated with the ideas of democracy and democratization, the latter understood as parallel with humanization. For Freire, humanization is an ontological vocation which cannot properly be acted on without hope and without a guiding vision as an objective of hope. Importantly, democratization as a utopian object of hope does not refer to the perfection of social conditions, neither can it be equated with a totalitarian process of Enlightenment that gradually progresses in the direction of a pre-given ideal. Rather, Freire's concept of democratization is driven by a criticism of present structural injustices, and thus the tangible steps towards democratization must be determined in every historical situation in relation to the "dehumanizing" injustices (Freire 1997, pp. 45-47, Freire 2004, p. 35) that exist in the current society. Democratization can be seen as a process of creation, re-creation and re-making which holds normative value while remaining fundamentally uncertain and open-ended. In Freire's view, all political struggle needs to be guided by a utopian vision to motivate everyday political contestation, and thus we argue that such vision is of crucial significance for fostering hope, despite the fact that the articulations of this vision are fundamentally provisional and re-definable. This idea is affirmed by Darren Webb (2010, also 2017) who argues that a normative visionary grounding is necessary for all transformative pedagogy, and by Torres (2009a) who suggests that utopia functions as "a political rationale" (p. 94) that keeps us on the move. Hence, for education to maintain - or better, regain-its transformative and political potential, we suggest that democratic education needs to search for ways to connect the utopian vision to concrete, realistic and pursuable political alternatives that are collectively and historically formed. As Freire (1998c, p. 31) states, "the object of hope has to be made".

Under the conditions of neoliberal common sense, the dominant discourses bind subjectivities to constant struggles to sustain their precarious positions in the present so that the only feasible means for taking possession of one's life is committing to continuous pursuit of empty objects of hope that the capitalist market economy predetermines and provides as given. In other words, individuals construct their identities, hopes and life-goals through affective, discursively held mechanisms, which ultimately function in the service of production and reproduction of the neoliberal market economy. Democratization thus requires collective formulation of tangible, alternative objects of hope that are not determined by economic rationalities and, furthermore, dialogical negotiation on how to work towards these objects. Democratization is thus a continuous, collective and transformative process of constructing concrete historical alternatives or "blueprints" (Webb 2017, p. 552) that depart from the present, all-immersive neoliberal common sense.

Freire stresses that the creation of such blueprints entails literacy-"reading of the world and the word" (Freire 1985, pp. 101-103, 1997, pp. 43-44, 1998a, p. 48, 1998c, p. 37, 2004, pp. 63-64)—which enables detecting the complex social and political relations and processes underlying the structures that delimit one's opportunities for thought, feeling and action. ${ }^{5}$ According to Barbara (2013), the great importance of Freire's work

\footnotetext{
5 Freire's idea of literacy is closely associated with his concept of conscientization, a "deepened reading of reality" or a way of "reading how society works" (Freire 1995, pp. 177-178), which allows one to understand better the operations of power within society. Conscientization is a process of distancing oneself from the experienced reality in order to perceive the power structures and relationships of the society and to understand how these relate to one's personal experience.
} 
to the theory of democratic education was to relate literacy to the struggles over cultural meaning. For Freire, literacy thus does not refer to technical reading skills but has a more comprehensive cultural and political meaning: it is related to political imagination, and the capacity to engage with texts and the world in a reflective, critical, and questioning manner, which further implies a rigorous attempt to understand, challenge, and transform oppressive social structures (Freire 1985, 1997, 1998c; Freire and Macedo 1987; see also Roberts 2000). Instead of focusing primarily on technical literacies and abstract knowledge, it is thus crucial for democratic education to remind us of the value of the multiple literacies, perspectives, knowledges and voices that must be involved in the literacy of the future that is needed to make democracy.

However, as Thayer-Bacon (2013) and Torres point out, critical consciousness and literacy cannot be imposed on students. Democratic education aims to hold and respect the latent ideas students themselves harbour and thus it helps them to find their ideals and construct their "blueprints" by themselves. The idea underlying such democratic education is that it aims to displace the ideals imposed on students by socialization, and thus it might give rise to meanings and ideas that have been absent or silenced in taken-for-granted neoliberal culture. (Torres 2012, 2013b; Torres and Morrow 2002.) Thus, it is crucial to focus on a collective search to find alternative goals and objects of desire to those appointed by neoliberalism and discover new and collective ways to make life meaningful with the help of these goals and objects.

Democratic education should particularly seek to make explicit the long term depolitizing and dehumanizing mechanisms and historical processes through which the current perceptions and discourses concerning democracy have become intertwined with capitalism. This can help students to discover alternative political ideals and blueprints concerning the organization of society and motivate them to engage in transformative political action, including non-formal, unofficial and alternative forms of political organization and democratic participation. To help in picturing these alternatives, and collectively pursuing them, democratic education needs to encourage and make legitimate wholly new forms and means of political participation. It should address questions concerning the meaning of democracy, such as what democracy can be and how could it be more than what it is at the present historical moment because, for Freire, democracy has a deeper and more radical meaning than that related to representative democracy.

\section{Conclusions}

Our aim in this paper was to demonstrate the enduring relevance of Freire's philosophy of hope to contemporary democratic education by demonstrating how the notion of hope is particularly fruitful for understanding the aims and purposes of democratic education under today's neoliberal restructuring. We attempted to show how these mechanisms associated with the so-called neoliberal common sense delimit individual action and thought by providing hopes, goals, and objects of desire which individuals adopt, and to which they become affectively attached, because they allow individuals to sustain their sense of purpose in life in historical conditions that present themselves as unalterable. However, as we have indicated, these mechanisms are destructive in the long run, and ultimately become impediments to ethical-political intervention and transformation, because they engage subjectivities in the continuous reproduction and sustenance of the structures that delimit political imagination and prevent subjects from embracing goals and objectives that would 
lead towards democratization. Thus, with this article, we have contributed to the conversation on how human will, desires and hopes are produced and shaped affectively, and how these processes and affective attachments are tied to the construction of the neoliberal subjectivity.

Furthermore, we utilized Freire's philosophy of hope to construct the core principles to guide democratic education that seeks to foster the virtue of hope under the conditions of neoliberal common sense. These intertwined principles, history as possibility, ethics of intervention, and democratization, highlight the need to find viable alternatives to the aforementioned affective objectives and goals provided by neoliberal common sense, and to discover potentialities of transformation in the circumstances of today's advanced capitalist societies. These principles also stress the requirement to adopt an interventionist orientation towards the structures of society even when they appear to be unalterable. Moreover, these principles call for utopian political imagination directed towards concrete, pursuable visions that are constructed through a critical reading of the present economic, social and political structures. Our claim is that these principles together establish a foundation for democratic education that fosters the virtue of hope, thus preventing adaptation to the affective mechanisms associated with the neoliberal common sense. Hence, Freire's concept of hope, and the central principles associated with it, still entail an enormous potential for reviving the political dimensions of education and thus contributing to the transformation of the society.

Acknowledgements Open access funding provided by University of Helsinki. The research has been conducted as a part of the research project "Interrupting Youth Support Systems in the Ethos of Vulnerability" (Academy of Finland, 2017-2021). The research has been funded by the University of Helsinki (SEDUCE doctoral programme), Academy of Finland (project "Democracy, Education and the Challenge of Inclusion: Reconstructing a Theory of Citizenship Education for Contemporary Democracies", 2017-2020) and the KONE Foundation. We would like to thank the members of the "Cross-sectoral policies and educational practices in the era of multiple crises" (CRISP) - research group and the participants of the Philosophy of education research seminar at the University of Helsinki for their invaluable comments on the earlier versions of this manuscript. Funding was provided by Helsingin Yliopisto (FI), Kulttuurin ja Yhteiskunnan Tutkimuksen Toimikunta (Grant No. 308934), and Kulttuurin ja Yhteiskunnan Tutkimuksen Toimikunta (Grant No. 308018).

Open Access This article is distributed under the terms of the Creative Commons Attribution 4.0 International License (http://creativecommons.org/licenses/by/4.0/), which permits unrestricted use, distribution, and reproduction in any medium, provided you give appropriate credit to the original author(s) and the source, provide a link to the Creative Commons license, and indicate if changes were made.

\section{References}

Berlant, Laurent. 2011. Cruel optimism. London: Duke University Press.

Biesta, Gert. 2014. The Beautiful risk of Education. London: Paradigm publishers.

Bovens, Luc. 1999. The value of hope. Philosophy and Phenomenological Research 59 (3): 667-681.

Brunila, Kristiina, and Päivi Siivonen. 2016. Preoccupied with the self: Towards self-responsible, enterprising, flexible and self-centred subjectivity in education. Discourse: Studies in the Cultural Politics of Education 37 (1): 56-69. https://doi.org/10.1080/01596306.2014.92772.

Buber, Martin. 2004. I and thou, 1st ed. London: Continuum.

Callan, Eamon. 1997. Creating citizens. Political education and liberal democracy. Oxford: Clarendon Press.

Cho, Seehwa. 2010. Politics of critical pedagogy and new social movements. Educational Philosophy and Theory 42 (3): 310-325. 
Crapanzano, Vincent. 2003. Reflections on hope as a category of social and psychological analysis. Cultural Anthropology 18 (1): 3-32.

Davies, Bronwyn. 2005. The (im)possibility of intellectual work in neoliberal regimes. Discourse: Studies in the Cultural Politics of Education 26 (1): 1-14.

Day, John Patrick. 1991. Hope a philosophical inquiry. Helsinki: Philosophical Society of Finland.

De Lissovoy, Noah. 2007. Frantz Fanon and the materialist critical pedagogy. In Critical pedagogy: Where are we now?, ed. McLaren Peter and J.L. Kincheloe, 355-370. New York: Peter Lang.

Ellsworth, Elisabeth. 1989. Why doesn't this feel empowering? Working through the repressive myths of critical pedagogy. Harvard Educational Review 59 (3): 297-324.

Fischman, Gustavo E., and Eric Haas. 2009. Critical pedagogy and hope in the context of neo-liberal globalization. In Critical pedagogy: Where are we Now?, ed. Peter McLaren and Joe Kincheloe, 565-575. New York: Peter Lang.

Freire, Paulo. 1978. Pedagogy in process. London: Writers and Readers Publishing Cooperative.

Freire, Paulo. 1985. The politics of education: Culture, power, and liberation. Massachusetts: Bergin \& Garvey Publishers.

Freire, Paulo. 1993a. Pedagogy of the city. New York: Continuum.

Freire, Paulo. 1993b. Pedagogy of the oppressed. London: Penguin books.

Freire, Paulo. 1995. Learning to read the world. Paulo Freire in conversation with Carlos Alberto Torres. In Education and social change in Latin America, ed. Carlos A. Torres, 175-183. Albert Park: James Nicholas Publishers.

Freire, Paulo. 1996. Letters to Christina: Reflections on my life and work. London: Routledge.

Freire, Paulo. 1997. Pedagogy of the heart. New York: Continuum.

Freire, Paulo. 1998a. Politics and education. Los Angeles: UCLA Latin American Center publications.

Freire, Paulo. 1998b. Pedagogy of freedom: Ethics, democracy and civic courage. New York: Rowan \& Littlefield publishers.

Freire, Paulo. 1998c. Pedagogy of hope: Reliving pedagogy of the oppressed. New York: Continuum.

Freire, Paulo. 1970a. The adult literacy process as cultural action for freedom. Harvard Educational Review 40 (2): 205-225.

Freire, Paulo. 1970b. Cultural action and conscientization. Harvard Educational Review 40 (3): 452-477.

Freire, Paulo. 2003. Education for critical consciousness. New York: Continuum.

Freire, Paulo. 2004. Pedagogy of indignation. London: Paradigm Publishers.

Freire, Paulo. 2014. Pedagogy of solidarity. Walnut Creek, CA: Left Coast Press.

Freire, Paulo, and Ira Shor. 1987. A pedagogy for liberation. London: Macmillan.

Freire, Paulo, and Donaldo Macedo. 1987. Literacy: Reading the word and the world. London: Routledge.

Glass, R.D. 2001. On Paulo Freire's philosophy of praxis and the foundations of liberation education. Educational Researcher 30 (2): 15-25.

Gutmann, Amy. 1987. Democratic education. Princeton: Princeton University Press.

Halpin, David. 2003. Hope and education: The role of the utopian imagination. New York: Routledge.

Jackson, Sue. 2007. Freire re-viewed. Educational Theory. 57 (2): 199-213.

Kadlac, Adam. 2014. The virtue of hope. Ethical Theory \& Moral Practice 18 (2): 337-354.

Lather, Patti. 1998. Critical pedagogy and its complicities: A praxis of stuck places. Educational Theory 48 (4): 487-497.

Meyer, Iris. 2010. Hope as conscious action towards an open future. In Hope against hope: philosophies, cultures and politics of possibility and doubt. Series: At the Interface/Probing the Boundaries, Vol. 67, Leiden, 97-110. The Netherlands: Brill I Rodopi.

Mittleman, Alan. 2009. Hope in a democratic age: Philosophy, religion, and political theory. Oxford: University Press.

Moellendorf, Darrel. 2006. Hope as political virtue. Philosophical Papers 35 (3): 413-433.

Paolantonio, Mario. 2016. The cruel optimism of education and education's implication with 'passingon'. Journal of philosophy of Education 50 (2): 147-159.

Roberts, Peter. 2000. Education, liberation, and humanization: exploring the work of Paulo Freire. Westport: Bergin and Garvey.

Roberts, Peter. 2008. Reason, emotion and politics in the work of Paulo Freire. In Social Justice Education for Teachers, ed. Carlos A. Torres and P. Noguera, 101-117. Taipei: Sense Publishers.

Smith, Nicholas. H. 2010. From the concept of hope to the principle of hope. In Hope against hope: Philosophies, Cultures, and politics of possibility and doubt. Series: At the Interface/Probing the Boundaries, Vol. 67 Leiden, 3-22. The Netherlands: Brill I Rodopi https:/www.academia. edu/1284912/From_the_concept_of_hope_to_the_principle_of_hope. 
Thayer-Bacon, Barbara. 2013. Democracies always in the making: historical and current philosophical issues for education. New York: Rowan and Littlefield.

Torres, Carlos A. 1994. Education and archaeology of consciousness-Freire and Hegel. Educational theory 44 (4): 429-455.

Torres, Carlos A. 1998. Democracy, education and multiculturalism-Dilemmas of citizenship in a global world. New York: Rowan \& Littlefield.

Torres, Carlos A. 1999. Critical theory and political sociology of education: arguments. In Critical theories in education: Changing terrains of knowledge and politics, ed. Thomas S. Popkewitz and Lynn Fendler, 87-116. New York: Routledge.

Torres, Carlos A. 2011. Public universities and the neoliberal common sense: Seven iconoclastic theses. International Studies in Sociology of Education 21 (3): 177-197.

Torres, Carlos A. 2012. Critical social theory: a portrait. Ethics and Education. 7 (2): 115-124.

Torres, Carlos A. 2009a. Education and neoliberal globalization. New York: Routledge.

Torres, Carlos A. 2009b. Globalizations and education. Collected essays on class, race, gender and the state. New York: Teachers College Press.

Torres, Carlos A. 2013a. Neoliberalism as a new historical bloc: A gramscian analysis of neoliberalism's common sense in education. International Studies in Sociology of Education. 23 (2): 80-106.

Torres, Carlos A. 2013b. Political sociology of adult education. Rotterdam: Sense Publishers.

Torres, Carlos A. 2014. The first Freire. Early writings in social justice education. New York: Teachers College Press.

Torres, Carlos A., and Raymond A. Morrow. 2002. Reading Freire and Habermas-Critical pedagogy and transformative social justice learning. New York: Teachers College press.

Torres, Carlos.A., and Richard Heertum. 2011. Educational reform in the U.S. In the past 30 years: Great expectations and the fading American dream. In Educating the global citizen-"In the shadow of neoliberalism: thirty years of educational reform in North America, ed. Liliana Olmos, Carlos Alberto Torres, and Rich Van Heertum, 3-27. Los Angeles: UCLA. https://doi.org/10.2174/978160805268411 101010 iii.

Van Hooft, S. 2011. Hope. Acumen Publishing. https://doi.org/10.1017/upo9781844652617.002.

Webb, Darren. 2010. Paulo Freire and the need for a kind of education in hope. Cambridge Journal of Education in Hope 40 (4): 327-339.

Webb, Darren. 2013. Process, orientation and system: The pedagogical orientation of utopia in the work of Paulo Freire. Educational Theory 62 (5): 593-608.

Webb, Darren. 2017. Educational archaeology and the practice of utopian pedagogy. Pedagogy, Culture \& Society 25 (4): 551-566.

Weiler, Kathryn. 1996. The myths of Paulo Freire. Educational Theory 46 (3): 353-371.

Weiler, Kathryn. 2001. Reading Paulo Freire. In Feminist engagements: reading, resisting, re-visioning male theorists in education and cultural studies, ed. K. Weiler, 67-87. New York: Routledge.

White, Patricia. 1996. Civic virtues and public schooling: Educating citizens for a democratic society. New York: Teachers College Press.

Publisher's Note Springer Nature remains neutral with regard to jurisdictional claims in published maps and institutional affiliations. 